\title{
Use of Second Generation Tyrosine Kinase Inhibitors for Second-Line Treatment of Chronic Myeloid Leukemia After Imatinib Failure
}

\author{
Yahya BUYUKASIK \\ Hacettepe University Faculty of Medicine, Department of Hematology, Ankara, TURKEY
}

\begin{abstract}
Invention of imatinib was a great step for much more successful clinical management of chronic myeloid leukemia (CML). Now, two other tyrosine kinase inhibitors (TKIs) are available both for first-line and later treatments of CML. In Turkey, currently 2 nd line TKls are indicated only for imatinib failure. This review will evaluate indications for changing imatinib with dasatinib or nilotinib, success of the 2 nd line agents in the second-line treatment and some important properties of these agents.

Keywords: Chronic myeloid leukemia, Targeted therapy, Imatinib, Dasatinib, Nilotinib
\end{abstract}

\section{ÖZET}

İmatinib Başarısızığı Sonrası İkinci Nesil Tirozin Kinaz İnhibitörlerinin Kronik Miyeloid Lösemi'nin İkinci Basamak Tedavisi İçin Kullanılması

Imatinib'in geliştirilmesi, kronik miyeloid lösemi'nin (KML) çok daha başarılı klinik yönetimi için büyük bir adım olmuştur. Günümüzde KML'nin hem birinci hem de sonraki basamak tedavileri için iki tirozin kinaz inhibitörü (TKI) daha vardır. Türkiye'de günümüzde ikinci nesil TKi'ler yalnızca imatinib başarııızlı̆ıı için ruhsatlanmış durumdadır. Bu derlemede imatinib'i dasatinib ya da nilotinib ile değiştirme indikasyonları, ikinci basamak tedavide ikinci nesil ajanların başarıları ve bu ajanların bazı önemli özellikleri değerlendirilecektir.

Anahtar Kelimeler: Kronik miyeloid lösemi, Hedeflenmiş tedavi, Imatinib, Dasatinib, Nilotinib 


\section{INTRODUCTION}

In chronic phase (CP) chronic myeloid leukemia (CML) patients treated with imatinib as the firstline treatment agent, indications for changing therapy to a second generation tyrosine kinase inhibitor (TKI) should be considered in 3 conditions: ${ }^{1}$

1. Imatinib intolerance

2. Imatinib resistance

3. Suboptimal response to imatinib

\section{Imatinib Intolerance}

As cross intolerance is not expected except for hematologic toxicity, any of the second generation TKIs can be selected in patients with imatinib intolerance. Side effects which are mentioned in Table 1 and comorbidities may be considered during drug selection.

\section{Imatinib Resistance and Second-line Treatment}

There are many different pathophysiologic mechanisms for imatinib resistance, including BCR-ABL kinase domain mutations preventing imatinib binding, clonal evolution, BCR-ABL amplification/ over-expression, and decreased imatinib bioavailability/cell exposure. Mutations (notably T315I, $\mathrm{Y} 253 \mathrm{~F} / \mathrm{H}$, and $\mathrm{E} 255 \mathrm{~K} / \mathrm{V}$ ) and clonal evolution are the most important mechanisms. ${ }^{2}$ They are related to each other. BCR-ABL mutations have been reported in $36 \%$ to $55.7 \%$ of all chronic myeloid leukemia patients failing imatinib therapy. ${ }^{3-5}$ Mutation frequency ranged from $27 \%$ to $55 \%$ in chronic phase, $50 \%$ to $59.2 \%$ in accelerated phase (AP), and 47.6 to $79.4 \%$ in blastic crisis (BC) or BCR$\mathrm{ABL}+$ acute lymphoblastic leukemia (ALL).-7

Table 1. Important characteristics of the second generation TKIs that may help drug selection (according to FDA and EMEA labels)

\begin{tabular}{|c|c|c|c|c|c|}
\hline & Preferable & $\begin{array}{l}\text { Contraindi- } \\
\text { cations } \\
\text { (According } \\
\text { to FDA or } \\
\text { EMEA lebels) }\end{array}$ & $\begin{array}{l}\text { Condition } \\
\text { to be careful } \\
\text { (According } \\
\text { to FDA or } \\
\text { EMEA lebels) }\end{array}$ & $\begin{array}{l}\text { Warnings and precautions } \\
\text { (According to FDA or EMEA lebels) }\end{array}$ & Others \\
\hline Dasatinib & $\begin{array}{l}\text {-Blastic crisis } \\
\mathrm{Ph}^{+} \text {acute } \\
\text { lymphoblastic } \\
\text { leukemia } \\
\text {-Nilotinib- } \\
\text { resistant } \\
\text { mutations: } \\
\text { Y253H, } \\
\text { E255V, } \\
\text { E255K, } \\
\text { F359C }\end{array}$ & $\begin{array}{l}\text {-Hypersensitivity } \\
\text { to drug } \\
\text { constituents }\end{array}$ & $\begin{array}{l}\text {-Antiplatelet or } \\
\text { anticoagulant } \\
\text { drug therapies } \\
\text {-Patients with } \\
\text { long QT or at } \\
\text { risk for pro- } \\
\text { longation } \\
\text {-Moderate- } \\
\text { severe liver } \\
\text { dysfunction } \\
\text {-CYP3A4 } \\
\text { substrates with } \\
\text { narrow thera- } \\
\text { peutic index. }\end{array}$ & $\begin{array}{l}\text {-Periodic CBC analysis required due to myelosupression risk. } \\
\text {-Bleeding events that are mostly related to thrombositopenia } \\
\text { (and occuring more frequently in accelerated phase/blastic } \\
\text { crisis). Severe central nervous system and gastrointestinal } \\
\text { hemorrhages, including fatalities, are observed. } \\
\text { Gastrointestinal hemorrhage may require treatment } \\
\text { interruptions and transfusions. } \\
\text {-Sometimes significant fluid retention (ascites, edema, pleural } \\
\text { and pericardial effusions). Appropriate precautions should be } \\
\text { taken. } \\
\text {-Be careful in patients with long QT or at risk for QT } \\
\text { prolongation. } \\
\text {-Significant cardiac events were reported during treatment } \\
\text { (1.6\% cardiomyopathy, heart failure, myocardial infarction) } \\
\text {-May cause fetal harm when administered to a pregnant } \\
\text { women }\end{array}$ & $\begin{array}{l}\text {-Heart disease, hypertension } \\
\text { and twice daily use of dasa- } \\
\text { tinib have been found as risk } \\
\text { factors for pleural effusion } \\
\text { in a retrospective study. } \\
\text {-Dasatinib has been found } \\
\text { to cause platelet function } \\
\text { defects in in vitro tests and } \\
\text { animal studies. Clinical } \\
\text { importance of these findings } \\
\text { are not clear. }\end{array}$ \\
\hline Nilotinib & $\begin{array}{l}\text {-Dasatinib- } \\
\text { resistant } \\
\text { mutations } \\
\text { F317L and } \\
\text { V299L }\end{array}$ & $\begin{array}{l}\text {-Hypokalemia } \\
\text {-Hypomagnesemia } \\
\text {-Long QT syndrome } \\
\text {-Hypersensitivity to } \\
\text { drug constituents }\end{array}$ & $\begin{array}{l}\text {-Liver disfunction } \\
\text {-History of pancreatitis } \\
\text {-Coronary artery } \\
\text { disease or risk } \\
\text { factors, conges- } \\
\text { tive heart failure, } \\
\text { clinically signifi- } \\
\text { cant bradicardia } \\
\text {-Drugs carrying risk } \\
\text { of QT prolongation } \\
\text {-Patients taking } \\
\text { CYP3A4, CYP2C8, } \\
\text { CYP2C9, CYP2D6, } \\
\text { or UGT1A1 enzyme } \\
\text { substrates with } \\
\text { narrow therapeutic } \\
\text { index } \\
\text {-Patients taking Pgp } \\
\text { inhibitors }\end{array}$ & $\begin{array}{l}\text {-CBC every } 2 \text { weeks for } 2 \text { months and then every month. } \\
\text {-EKG within one week before treatment and periodically } \\
\text { thereafter and at dose modifications due to QT prolongation } \\
\text { risk. For similar reason electrolyte monitoring and meticulous } \\
\text { correction of hypokalemia/hypomagnesemia are important. } \\
\text { Avoid use of QT prolonging agents and CYP3A4 inhibitors. } \\
\text {-Sudden death was reported ( } \sim 0.6 \% \text { in > } 1 \text { study). } \\
\text {-Lipase, liver enzymes and bilirubin monitoring due to frequent } \\
\text { elevations. } \\
\text {-CYP3A4 inhibitors and activators are to be avoided. Nilotinib } \\
\text { dose reductions or close QT monitoring are appropriate in } \\
\text { patients using CYP3A4 inhibitors. } \\
\text {-Food may increase blood levels. Avoid food } 2 \text { hours before } \\
\text { and } 1 \text { hour after the drug. } \\
\text {-May cause fetal harm when administered to a pregnant women. }\end{array}$ & $\begin{array}{l}\text {-Considerable risk of } \\
\text { hyperglisemia. Importance of } \\
\text { this side effect in diabetic } \\
\text { patients and those with } \\
\text { cardiovascular risks factors } \\
\text { is not clear. }\end{array}$ \\
\hline
\end{tabular}




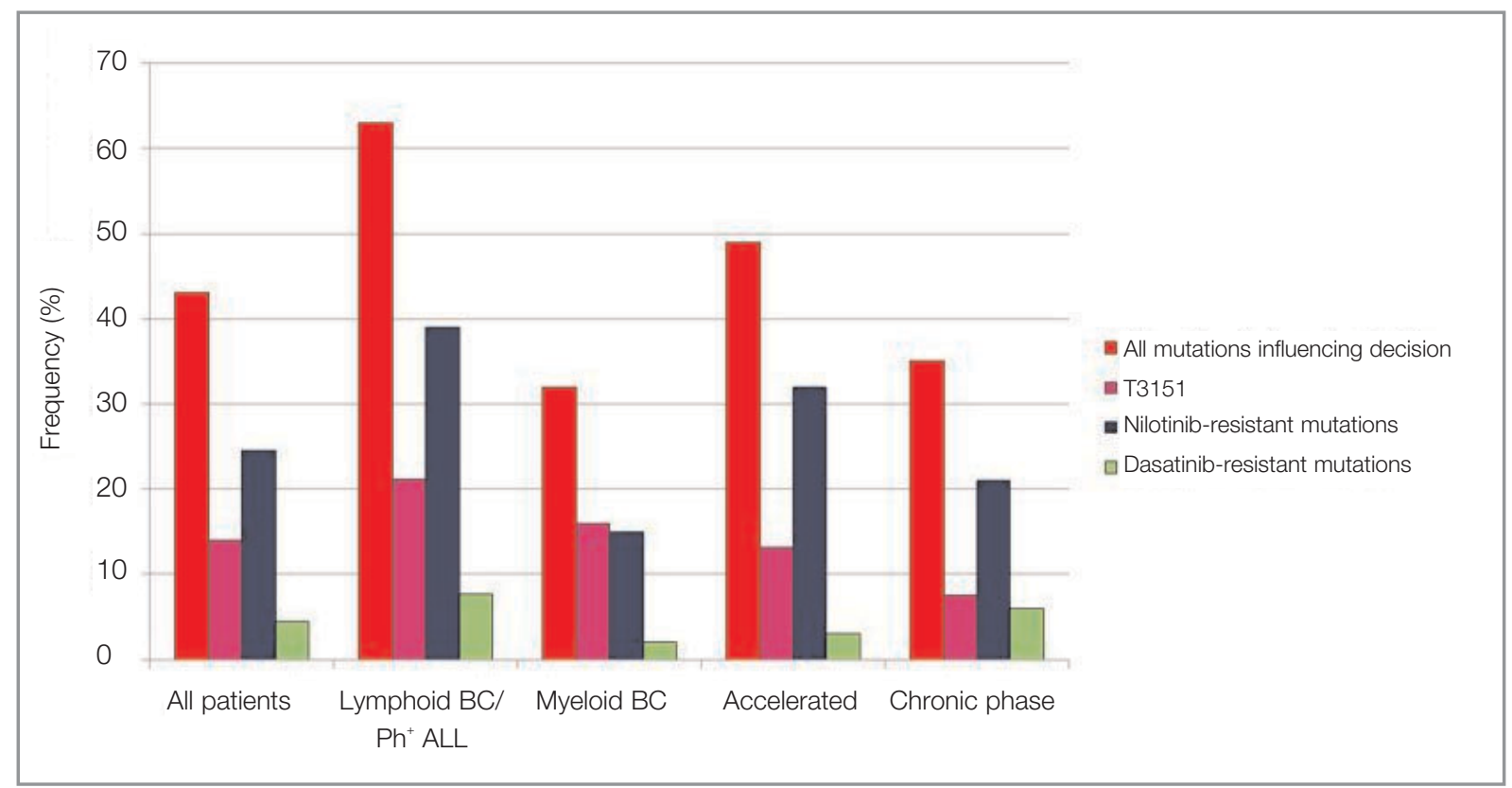

Figure 1. Frequency of imatinib-resistant chronic myeloid leukemia patients with mutations where one or more of their mutations would influence the treatment decision. The frequencies are percentages of all patients with BCR-ABL mutations. Adapted from reference 15 with modifications depending on approximate data presented in this reference.

Imatinib dose escalation, second generation TKIs and allogeneic stem cell transplantation are treatment options for imatinib-resistant cases. Many patients do not achieve a worthwhile response to higher doses of imatinib and the majority of responders will gradually lose their initially good response. Therefore, for patients who fail imatinib, changing treatment to a second-generation TKI is the best option..$^{8-13}$ If a patient is relatively young and has a suitable HLA-matched donor, then allogeneic stem cell transplantation should also be considered. ${ }^{14}$ Resistance to second generation TKIs and BCR-ABL T315I mutation are absolute indications for the transplantation. In a transplant-eligible patient with good response to second generation TKI treatment, whether to continue with pharmacotherapy or to transplant is a clinical dilemma.

When selecting a second generation TKI, BCRABL kinase domain mutations and patient co-morbidities may be considered. Table 1 summarizes clinically important properties of the second generation TKIs which may be useful during drug selection.

In a large series, $43 \%$ of imatinib resistant/BCRABL-mutated patients had one or more second generation inhibitor clinically relevant mutations, i.e., mutations insensitive to nilotinib and/or dasatinib.$^{15}$ Rates of the patients with clinically relevant mutations were $35 \%$ in chronic phase, $49 \%$ in AP, $32 \%$ in myeloid $\mathrm{BC}$, and $63 \%$ in lymphoid $\mathrm{BC} / \mathrm{BCR}-$ ABL+ ALL. Frequencies of those with nilotinibresistant mutations $(\mathrm{Y} 253 \mathrm{H}, \mathrm{E} 255 \mathrm{~K} / \mathrm{V}$, and $\mathrm{F} 359 \mathrm{~V} / \mathrm{C}$ ) were $\sim 21 \%, \sim 32 \%, \sim 15 \%$, and $\sim 39 \%$ in chronic phase, AP, myeloid $\mathrm{BC}$, and lymphoid BC/BCR-ABL+ ALL, respectively. V299L occurred rarely. Patients harboring the other dasatinib-resistant mutation, $\mathrm{F} 317 \mathrm{~L}$, were $6 \%, \leq 5 \%, \leq$ $5 \%$, and $7.7 \%$. T315I was carried by $7.5 \%, 13.2 \%$, $16 \%$, and $21.2 \%$ of imatinib resistant/BCR-ABLmutated patients in $\mathrm{CP}$, AP, myeloid BC, and lymphoid BC/BCR-ABL+ ALL, respectively (Figure 1).

Depending on the presented data, an algorithm for selection of second generation TKIs is presented in Figure 2.

\section{Suboptimal Response to Imatinib}

Clinical studies evaluating suboptimal responders showed relatively unfavourable prognosis. Hammersmith data revealed worse complete remission, stable complete remission, overall survival (OS) or progression-free survival (PFS) results in subopti- 


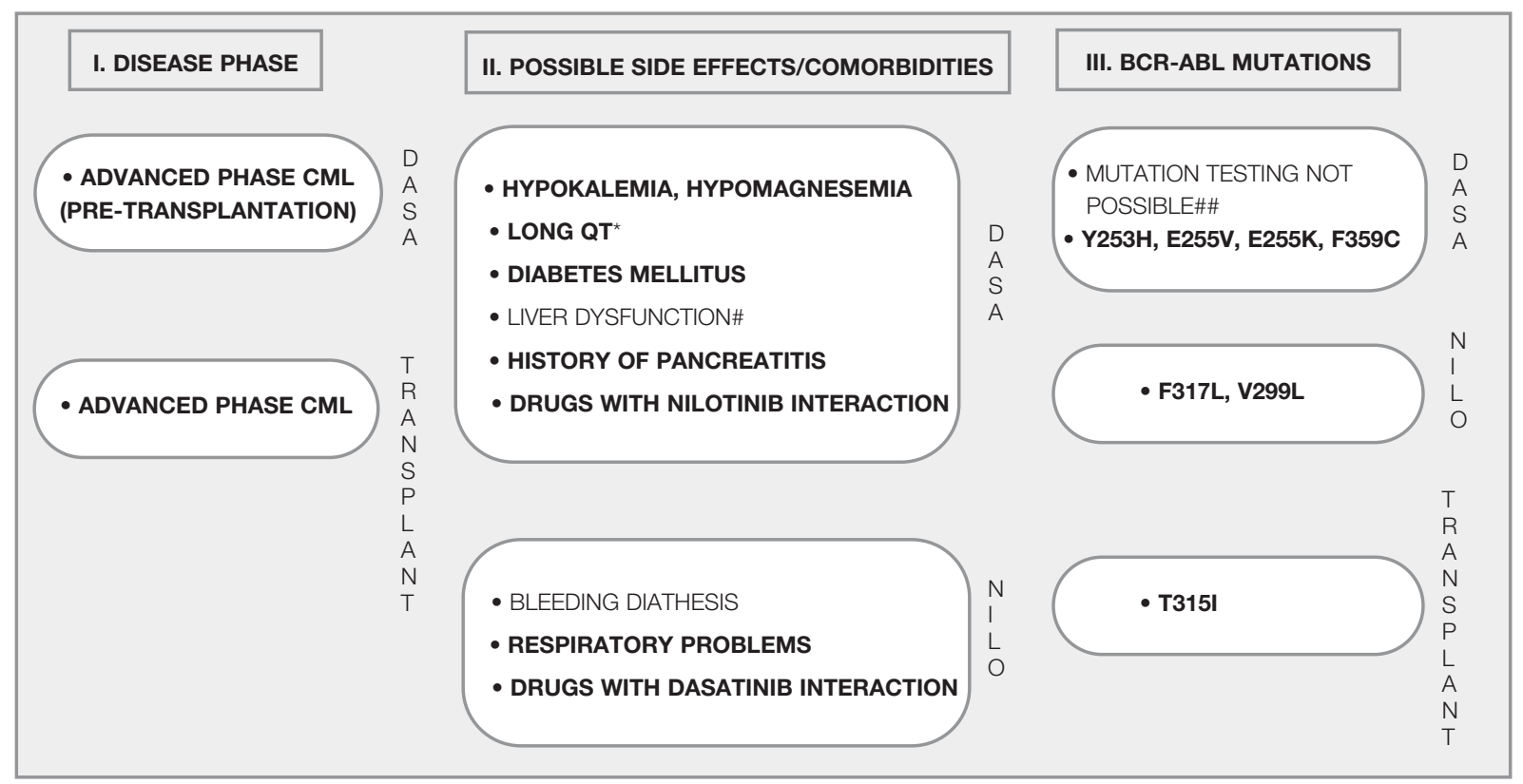

Figure 2. Evaluations during second generation tyrosine kinase inhibitor selection in a chronic myeloid leukemia (CML) patient with imatinib failure. This algorithm depends on contraindications, warnings and frequent side effects indicated in drug labels. Conditions constituting risks for both drugs (e.g. heart failure) are not demonstrated. Side effect (e.g. pleural effusion) prediction studies depending on retrospective data of low evidence level are not considered. Bold letters indicate conditions where one of the drugs is clearly more suitable. The drug of choice is shown beside the boxes.

* Both of the drugs may cause QT prolongation.

\# Moderate-severe liver dysfunction and heart disorders are conditions to be careful also for dasatinib.

\#\# Mutation screening is very important for second-line treatment planning in imatinib-resistant cases. Omitting of mutation analysis may be harmful.

mal response cases depending on the time period when this response occurred..$^{16}$ Similar results were also observed in a GIMEMA study. ${ }^{17}$ In this study, suboptimal responders at 6 th or 12 th months attained worse ultimate complete cytogenetic response (CCyR), major molecular response (MMR) and event-free survival (EFS) compared to optimal response patients. Prognosis of the 6th month suboptimal responders (i.e., patients showing minor or minimal cytogenetic responses at this time) was also evaluated in the IRIS study. ${ }^{18} \mathrm{EFS}$ rate was lower $(58 \%)$ in suboptimal response patients in comparison to those having optimal response (85-91\%). Survival rates without AP/BC transformation at 6 th year were $85 \%$ and $94-97 \%$, respectively. The chances of attaining CCyR were $54 \%$ and $87 \%$ in suboptimal and partial cytogenetic response cases, respectively. There are MD Anderson Cancer Center results supporting these data, too. ${ }^{19}$ In that study, the results of suboptimal responders - at 6 th month were especially striking.
Those cases had a very low possibility of ultimate CCyR (30\%), and EFS and transformation-free survival rates similar with imatinib failure patients. The transformation risk was $30 \%$.

Consequently, treatment modification should be preferred in these cases due to relatively unfavorable cumulative prognosis and uncertainty in which patient will finally reach to optimal response level. However, how to do this modification is not clear. Imatinib dose escalation or switch to second generation TKIs are possible alternatives. Although not confirmed with randomized clinical studies, second generation TKIs are probably a better option in this situation. European LeukemiaNet recommendations for the suboptimal response patients include continuation of imatinib at same dose, or testing of high dose imatinib, dasatinib, or nilotinib. ${ }^{1}$

During second-line treatment of imatinib-resistant CP CML patients, provisional definitions of responses to second-generation TKIs are presented in Table 2. 
Table 2. Provisional definition of the response to second-generation TKls, dasatinib and nilotinib, as second-line therapy of patients with imatinib-resistant chronic myeloid leukemia in chronic phase according to the European LeukemiaNet

\begin{tabular}{|c|c|c|c|}
\hline $\begin{array}{l}\text { Time of Evaluation } \\
\text { (months) }\end{array}$ & Suboptimal Response & Failure & Warnings \\
\hline Baseline & Not applicable & Not applicable & $\begin{array}{l}\text { Hematologic resistance to imatinib; } \\
\text { clonal chromosome abnor- } \\
\text { malities in } \mathrm{Ph}^{+} \text {cells; mutations }\end{array}$ \\
\hline 3 & $\begin{array}{l}\text { Minor cytogenetic response } \\
\left(\mathrm{Ph}^{+} 36-65 \%\right)\end{array}$ & $\begin{array}{l}\text { No cytogenetic response } \\
\left(\mathrm{Ph}^{+}>95 \%\right) ; \text { new mutations }\end{array}$ & $\begin{array}{l}\text { Minimal cytogenetic response } \\
\left(\mathrm{Ph}^{+} 66-95 \%\right)\end{array}$ \\
\hline 6 & $\begin{array}{l}\text { Partial cytogenetic response } \\
\left(\mathrm{Ph}^{+} 1-35 \%\right)\end{array}$ & $\begin{array}{l}\text { Minimal cytogenetic response } \\
\left(\mathrm{Ph}^{+} 66-95 \%\right) ; \text { new mutations }\end{array}$ & $\begin{array}{l}\text { Minor cytogenetic response } \\
\left(\mathrm{Ph}^{+} 36-65 \%\right)\end{array}$ \\
\hline 12 & $\begin{array}{l}\text { Less than major molecular } \\
\text { response }^{\star \star}\end{array}$ & $\begin{array}{l}\text { Less than partial cytogenetic } \\
\text { response }\left(\mathrm{Ph}^{+}>35 \%\right) ; \\
\text { new mutations }{ }^{\star}\end{array}$ & \\
\hline \multicolumn{4}{|c|}{ * TKI-insensitive BCR-ABL1 kinase domain mutations. } \\
\hline Rotin of $R C R=\cap R$ & 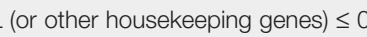 & $1 \%$ on the international scale & \\
\hline
\end{tabular}

Hematological toxicity and related complications may occur more frequently with the second generation TKIs due to higher drug potency. Some important characteristics of these agents (including important side effects) are summarized in Table 1. Pleural effusion under dasatinib and biochemical abnormalities, including hyperglycemia, bilirubin, liver enzyme, lipase, and amylase elevations under nilotinib are not infrequent. Dasatinib 100 mg QD instead of $70 \mathrm{mg}$ BID for CP CML and $140 \mathrm{mg}$ QD instead of 70 BID for advanced phases were found to cause significantly less pleural effusion and hematologic toxicities without impairing efficacy. 20-23

\section{CONCLUSION}

TKIs made treatment of CML easier and more successful. However, there are still many things to be done for more effective use of the modern armamentarium for the management of CML.

\section{REFERENCES}

1. Baccarani M, Cortes J, Pane F, et al. Chronic myeloid leukemia: An update of concepts and management recommendations of European LeukemiaNet. J Clin Oncol 27: 6041-6051, 2009.
2. Lahaye $T$, Riehm B, Berger $U$, et al. Response and resistance in 300 patients with BCR-ABL-positive leukemias treated with imatinib in a single center: a 4.5-year follow-up. Cancer 103: 659-669, 2005.

3. Jabbour E, Kantarjian H, Jones D, et al. Frequency and clinical significance of BCR-ABL mutations in patients with chronic myeloid leukemia treated with imatinib mesylate. Leukemia 20: 1767-1773, 2006.

4. Soverini S, Colarossi S, Gnani A, et al. Contribution of $\mathrm{ABL}$ kinase domain mutations to imatinib resistance in different subtypes of Philadelphia-positive patients: by the GIMEMA Working Party on Chronic Myeloid Leukemia. Clin Cancer Res 12: 7374-7379, 2006.

5. Ernst T, Erben P, Müller MC, et al. Dynamics of BCR$A B L$ mutated clones prior to hematologic or cytogenetic resistance to imatinib. Haematologica 93: 186-192, 2008.

6. Müller MC, Cortes JE, Kim DW, et al. Dasatinib treatment of chronic-phase chronic myeloid leukemia: analysis of responses according to preexisting BCRABL mutations. Blood 114: 4944-4953, 2009.

7. Hughes T, Saglio G, Branford S, et al. Impact of baseline BCR-ABL mutations on response to nilotinib in patients with chronic myeloid leukemia in chronic phase. J Clin Oncol 27: 4204-4210, 2009.

8. Talpaz M, Shah NP, Kantarjian H, et al. Dasatinib in imatinib-resistant Philadelphia chromosome-positive leukemias. N Engl J Med 354: 2531-2541, 2006.

9. Hochhaus A, Kantarjian HM, Baccarani M, et al. Dasatinib induces notable hematologic and cytogenetic responses in chronic-phase chronic myeloid leukemia after failure of imatinib therapy. Blood 109: 23032309, 2007. 
10. Hochhaus A, Baccarani M, Deininger M, et al. Dasatinib induces durable cytogenetic responses in patients with chronic myelogenous leukemia in chronic phase with resistance or intolerance to imatinib. Leukemia 22: 1200-1206, 2008.

11. Kantarjian $H$, Pasquini R, Lévy $V$, et al. Dasatinib or high-dose imatinib for chronic-phase chronic myeloid leukemia resistant to imatinib at a dose of 400 to 600 milligrams daily. Two-year follow-up of a randomized phase 2 study (START-R). Cancer 115: 4136-4147, 2009.

12. Kantarjian $H$, Giles F, Wunderle L, et al. Nilotinib in imatinib-resistant CML and Philadelphia chromosomepositive ALL. N Engl J Med 354: 2542-2551, 2006.

13. Kantarjian HM, Giles F, Gattermann N, et al. Nilotinib (formerly AMN107), a highly selective BCR-ABL tyrosine kinase inhibitor, is effective in patients with Philadelphia chromosome-positive chronic myelogenous leukemia in chronic phase following imatinib resistance and intolerance. Blood 110: 3540-3546, 2007.

14. Saussele S, Lauseker M, Gratwohl A, et al. Allogeneic hematopoietic stem cell transplantation (allo SCT) for chronic myeloid leukemia in the imatinib era: evaluation of its impact within a subgroup of the randomized German CML Study IV. Blood 115: 1880-1885, 2010.

15. Branford S, Melo JV, Hughes TP. Selecting optimal second-line tyrosine kinase inhibitor therapy for chronic myeloid leukemia patients after imatinib failure: does the BCR-ABL mutation status really matter? Blood 114: 5426-5435, 2009.

16. Marin D, Milojkovic D, Olavarria E, et al. European LeukemiaNet criteria for failure or suboptimal response reliably identify patients with CML in early chronic phase treated with imatinib whose eventual outcome is poor. Blood 112: 4437-4444, 2008.

17. Castagnetti F, Gugliotta G, Breccia M, et al. Suboptimal response to imatinib $400 \mathrm{mg}$ daily for chronic myeloid leukemia in early chronic phase: a GIMEMA CML WP analysis of 423 consecutive patients. Haematologica 94[suppl 2]: A0628, 2009.

18. Hochhaus A, O'Brien SG, Guilhot F, et al. Six-year follow-up of patients receiving imatinib for the first-line treatment of chronic myeloid leukemia. Leukemia 23: 1054-1061, 2009.

19. Alvarado $\mathrm{Y}, \mathrm{Kantarjian} \mathrm{H}, \mathrm{O}^{\prime}$ Brien S, et al. Significance of suboptimal response to imatinib, as defined by the European LeukemiaNet, in the long-term outcome of patients with early chronic myeloid leukemia in chronic phase. Cancer 115: 3709-3718, 2009.
20. Kantarjian H, Cortes J, Kim DW, et al. Phase 3 study of dasatinib $140 \mathrm{mg}$ once daily versus $70 \mathrm{mg}$ twice daily in patients with chronic myeloid leukemia in accelerated phase resistant or intolerant to imatinib: 15month median follow-up. Blood 113: 6322-6329, 2009.

21. Saglio G, Kantarjian $H$, Hochhaus A, et al. Dasatinib $140 \mathrm{mg}$ once daily (QD) demonstrates equivalent efficacy and improved safety compared with $70 \mathrm{mg}$ twice daily (BID) in patients with Chronic Myeloid Leukemia in Blast Phase (CML-BP): 2-Year Data from CA180035. 50th American Society of Hematology Annual Meeting and Exposition, San Francisco, December 69, 2008: P3226.

22. Shah NP, Kantarjian HM, Kim DW, et al. Intermittent target inhibition with dasatinib 100 mg once daily preserves efficacy and improves tolerability in imatinib-resistant and -intolerant chronic-phase chronic myeloid leukemia. J Clin Oncol 26: 3204-3212, 2008.

23. Shah NP, Kim DW, Kantarjian HM, et al. Dasatinib dose-optimization in chronic phase Chronic Myeloid Leukemia (CML-CP): Two-year data from CA180-034 show equivalent long-term efficacy and improved safety with 100 mg once daily dose. 50th American Society of Hematology Annual Meeting and Exposition, San Francisco, December 6-9, 2008: P3225.

\section{Correspondence}

Dr. Yahya BÜYÜKAŞIK

Hacettepe Üniversitesi Erişkin Hastaneleri

Hematoloji Ünitesi

06100 Sinhiye, Ankara / TURKEY

Tel: (+90.312) 3051543

Fax: (+90.312) 3051614

e-mail: ybuyukas@hacettepe.edu.tr 